\title{
Analisis Pemasaran Domba dari Tingkat Peternak Sampai Penjual Sate di Kabupaten Sleman
}

\author{
F.X. Suwarta dan G. Harmoko \\ Jurusan Peternakan, Fakultas Pertanian Universitas Mercu Buana, \\ Yogyakarta
}

\begin{abstract}
ABSTRAK
Penelitian ini bertujuan untuk mengetahui mata rantai tataniaga dan biaya ternak domba dari peternak, pedagang dan penjual sate di kabupaten Sleman Yogyakarta. Penelitian dilaksanakan dengan metode survei, dengan jumlah responden 107 orang peternak domba, 37 orang pedagang domba dan penjual sate 64 orang. Pengambilan data secara purposive random sampling. Analisis data penelitian dilakukan secara deskriptif dan analisis pemasaran meliputi biaya pemasaran, margin, farmer's share, kompetisi pasar dan analisis profitabilitas. Saluran tataniaga yang efisien adalah peternak, pedagang domba, konsumen. Berdasarkan analisis margin, penjualan ternak domba jantan memberikan margin yang lebih besar daripada ternak betina yaitu 19,78 dan 19,14\%. Analisis farmer share domba betina lebih besar daripada domba jantan yaitu 80,85 dan 80,21\%. Analisis kompetisi pasar menunjukkan koefisien kompetisi peternak domba lebih besar daripada pedagang domba, baik untuk ternak jantan maupun betina. Analisis net profit margin (NPM) diketahui lembaga tataniaga peternak domba mempunyai NPM tertinggi dan operating ratio terendah, sedangkan penjual sate memiliki NPM terendah dan operating ratio tertinggi.
\end{abstract}

Kata kunci : domba, pemasaran, efisiensi pemasaran

\section{Marketing Analysis of Sheep from Farmer to the Satay Seller in Sleman Regency}

\begin{abstract}
This aim of this research was to study marketing chain of sheeps from farmer, trader and satay seller and to study cost of marketing at each of instituted marketing and the revenue of farmer, trader and satay seller in Sleman regency, Yogyakarta. The research was conducted using a survey method. The respondents from sheep farmer, sheep trader and satay seller were 107, 37 and 64, respectively. Data were analyzed descriptively. The cost efficiency of marketing system was analyzed for marketing cost, margin, farmer's share, market competition and profitability. The result showed that the most efficient of the distribution of the sheep marketing was from sheep, farmer, sheep trader and consumer. Margin analyzed showed that male sheep contributed larger margin than female sheep (19.78: 19.14\%). The farmer share for sheep marketing revealed that female sheep contributed $80.85 \%$ while male sheep $80.21 \%$. Coefficiency of market competition showed that sheep farmer had higher coefficiency competition than sheep trader both to female and male. Sheep farmer had higher net profit margin (NPM) level but had lower operating ratio level. Satay seller had lower NPM and higher operating ratio level.
\end{abstract}

Key words : sheep, marketing, efficiency of marketing

\section{PENDAHULUAN}

Di Indonesia ternak domba mempunyai peranan penting sebagai penghasil daging, kulit dan penyedia lapangan kerja di perdesaan. Lebih dari $90 \%$ usaha peternakan domba diusahakan dalam bentuk peternakan rakyat. Menyempitnya penguasaan lahan yang digarap 
petani menjadikan ternak ruminansia kecil termasuk domba merupakan ternak alternatif yang dapat dikembangkan untuk meningkatkan pendapatan. Pada usaha tani dengan lahan sempit ternak domba mampu memanfaatkan tersedianya tenagakerja keluarga terluang semu (Abdulgani, 1981). Keberadaan ruminansia kecil dalam usaha tani dapat meminimalkan ketidakpastian dalam produksi tanaman di daerah kering dan mampu memanfaatkan limbah pertanian sebagai bahan pakan dan menghasilkan pupuk organik (Soedaryanto, 1990). Di Daerah Istimewa Yogyakarta, khususnya Kabupaten Sleman ternak domba dipelihara secara luas karena biaya produksi relatif rendah, mudah berkembang biak dan bila membutuhkan uang setiap saat mudah dijual.

Pemasaran ternak mempunyai peranan penting dalam sistem agribisnis peternakan (Limbong dan Sitorus, 1987). Sifat-sifat komoditas hasil peternakan yang berbeda dengan hasil industri, harus dijadikan acuan dalam perencanaan pemasaran, penetapan harga jual, pemilihan saluran distribusi serta pengelolaan sistem pengangkutan. Komoditas ternak domba memiliki fluktuasi harga jual cukup tinggi. Adanya ketidakpastian harga pasar berakibat kurang merangsang kegiatan produksi. Disamping itu matarantai tataniaga hasil pertanian yang panjang menjadikan tataniaga hasil peternakan kurang efisien, sehingga tidak mampu membagi pendapatan secara adil diantara berbagai lembaga tataniaga.

Kabupaten Sleman mempunyai potensi pasar daging domba cukup tinggi, Model pemasaran domba di kabupen Sleman sangat beragam, mulai dari saluran secara langsung dari peternak ke konsumen, peternak-pedagangkonsumen, peternak-pedagang pengumpulpedagang perantara-konsumen. Mengingat pentingnya pemasaran dalam sistem agribisnis domba, dilakukan kajian tentang analisis pemasaran domba di kabupaten Sleman.

\section{MATERI DAN METODE}

Penelitian ini ini dilaksanakan dengan cara survey menggunakan metode wawancara terhadap peternak, pedagang dan penjual sate di wilayah kabupaten Sleman. Pengambilan data dilakukan secara purposive random sampling. Jumlah responden terdiri dari peternak 107 orang, pedagang 37 orang dan penjual sate 64 orang. Data yang diambil meliputi identitas, biaya tataniaga, dan data saluran tataniaga ternak. Analisis data dilakukan secara deskriptif meliputi saluran tataniaga, biaya tataniaga, farmer's share, margin, efisiensi tataniaga dan profitabilitas meliputi net profit margin (NPM) dan operating ratio (OR).

\section{HASIL DAN PEMBAHASAN}

\section{Saluran Tataniaga}

Saluran tataniaga pemasaran ternak domba dari peternak sampai penjual sate di kabupaten Sleman dapat dilihat pada Gambar 1. Dari gambar tersebut, saluran tataniaga ternak domba sebagian besar menggunakan jasa blantik 55,1\%, dari peternak langsung ke pedagang $41,1 \%$ dan hanya $3,8 \%$ yang langsung ke penjual sate. Kondisi tersebut menunjukkan peranan blantik dalam distribusi ternak domba di wilayah Sleman, sangat penting. Peternak domba yang mampu menjual ternaknya sampai penjual sate sangat kecil hal ini karena peternak domba umumnya mempunyai skala usaha yang kecil sehingga kontinuitas penyediaan tidak terjamin, sehingga pedagang sate lebih mudah mendapatkan ternak dari pedagang.

\section{Biaya Tataniaga}

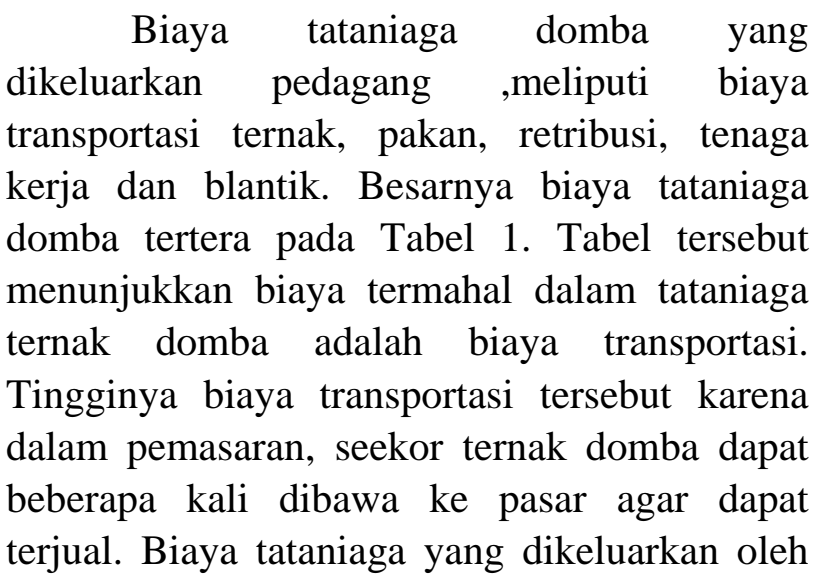




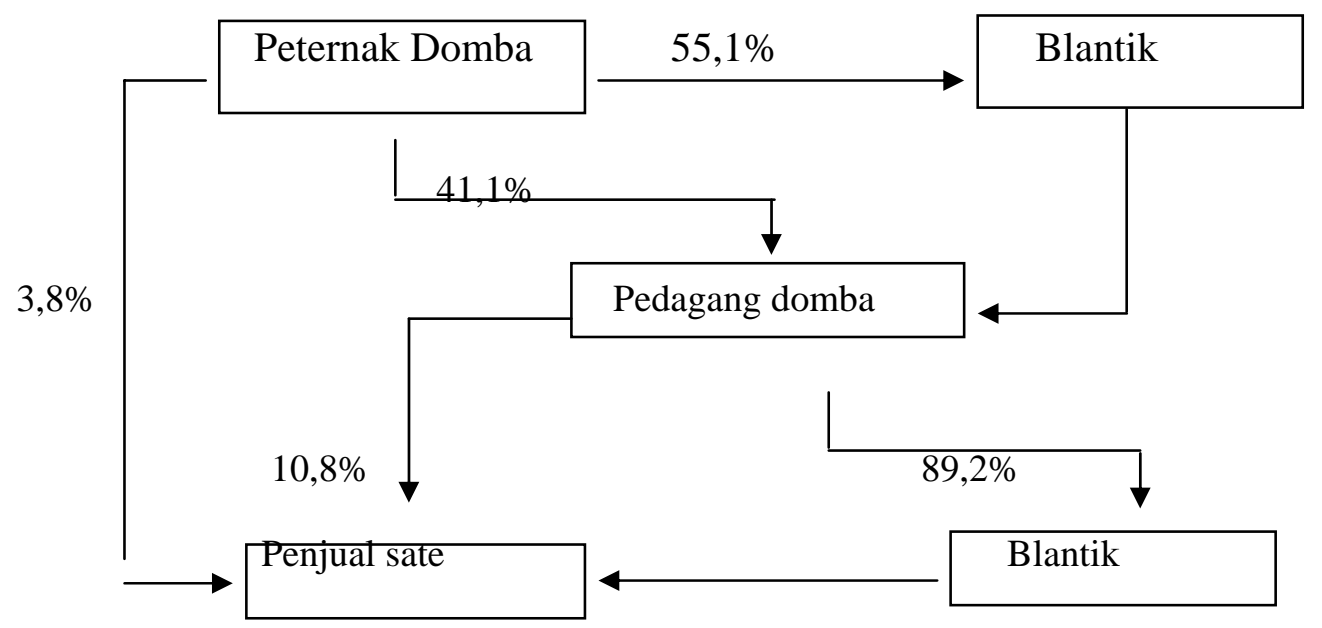

Gambar 1. Saluran tataniaga ternak domba di kabupaten Sleman

Tabel 1. Biaya tataniaga domba pada pedagang

\begin{tabular}{lcc}
\hline \hline Biaya tataniaga & Rata-rata (Rp/ekor) & Persentase (\%) \\
\hline Biaya transportasi pembelian & 10.000 & 18,69 \\
Biaya transportasi penjualan & 28.167 & 52,65 \\
Biaya pakan & 500 & 0,93 \\
Retribusi & 1.000 & 1,87 \\
Biaya tenaga kerja & 8.000 & 14,95 \\
Biaya blantik & 5.833 & 10,90 \\
\hline Jumlah & 53.500 & 100 \\
\hline
\end{tabular}

Tabel 2. Biaya tataniaga domba pada penjual sate

\begin{tabular}{lcc}
\hline \hline \multicolumn{1}{c}{ Biaya tataniaga } & Rata-rata (Rp/ekor) & Persentase (\%) \\
\hline Biaya tenaga kerja & 23.531 & 25,19 \\
Bumbu & 66.133 & 70,78 \\
Biaya peralatan & 685 & 7,33 \\
Retribusi & 333 & 0,36 \\
Biaya sewa tempat & 2.500 & 2,68 \\
Biaya pajak & 250 & 0,27 \\
\hline Jumlah & 93.432 & 100 \\
\hline
\end{tabular}

Tabel 3. Pendapatan lembaga tataniaga domba (Rp/ekor)

\begin{tabular}{|l|c|c|c|}
\hline Tataniaga & Pembelian biaya & Penjualan & Pendapatan \\
\hline Pedagang (domba betina) & $677.194,5$ & $777.517,9$ & $100.323,4$ \\
\hline Pedagang (domba jantan) & $611.666,7$ & $690.355,6$ & $78.689,0$ \\
\hline Penjual sate (domba betina) & $884.998,0$ & $1.056 .666,7$ & $171.668,9$ \\
\hline Penjual sate (domba jantan) & $797.835,7$ & $1.056 .666,7$ & $258.831,0$ \\
\hline
\end{tabular}


penjual sate meliputi biaya tenaga kerja, bumbu, peralatan, retribusi, sewa tempat dan pajak, selengkapnya tertera dalam Tabel 2 .

\section{Pendapatan Lembaga Tata Niaga}

Pendapatan lembaga tataniaga (pedagang dan penjual sate) dihitung berdasarkan selisih antara penjualan produk dengan harga pembelian ternak dan biaya yang dikeluarkan (Saefudin dan Hanafiah, 1986). Pendapatan tersebut disampaikan pada Tabel 3. Tabel tersebut menunjukkan bahwa pedagang sate mempunyai pendapatan lebih tinggi dibandingkan dengan pedagang baik untuk domba jantan dan betina.

\section{Margin dan farmer share}

Margin dihitung berdasarkan selisih harga dari peternak sampai harga jual domba dari pedagang ke penjual sate. Farmer's share merupakan persentase perbandingan antara harga di tingkat peternak dengan harga eceran ditingkat konsumen (Wiguna, 1984). Hasil perhitungan margin dan farmer's share tertera pada Tabel 4. Tabel tersebut menunjukkan nilai farmer,s share untuk domba relatif tinggi, hal ini berarti bagian harga yang diterima peternak cukup tinggi yaitu $80,21 \%$ untuk ternak betina dan $80,85 \%$ untuk ternak jantan.

\section{Efisiensi Tataniaga}

Penghitungan efisiensi pasar didasarkan pada volume produksi dari masing-masing saluran tataniaga dan dihitung berdasarkan koefisien kompetisi pasar. Volume produksi peternak di kabupaten Sleman sebesar 0,016 ekor/hari, pedagang 0,63 ekor/hari dan penjual sate 1,3 ekor/hari. Koefisien kompetisi pasar untuk ternak jantan dari peternak sebesar 2,08, sedang ternak betina 1,49. Koefisien kompetisi pasar pedagang untuk ternak jantan sebesar 1,14 dan ternak betina sebesar 1,12. Selain itu, ternak jantan memberikan koefisien kompetisi pasar yang lebih besar dibandingkan dengan ternak betina.

Tabel 4. Margin dan farmer's share tataniaga domba di kabupaten Sleman

\begin{tabular}{|l|c|c|c|c|c|}
\hline Domba & $\begin{array}{c}\text { Pembelian } \\
(\mathrm{Rp})\end{array}$ & $\begin{array}{c}\text { Penjualan } \\
(\mathrm{Rp})\end{array}$ & Margin (Rp) & Margin (\%) & $\begin{array}{c}\text { Farmer share } \\
(\%)\end{array}$ \\
\hline Jantan & $623.694,5$ & $777.517,9$ & $153.823,4$ & 19,78 & 80,21 \\
\hline Betina & $558.166,7$ & $690.355,6$ & $132.189,0$ & 19,14 & 80,85 \\
\hline
\end{tabular}

Tabel 5. Laba bersih masing-masing lembaga tataniaga ternak domba (Rp)

\begin{tabular}{|l|c|r|r|r|}
\hline Lembaga & $\begin{array}{l}\text { Produksi } \\
\text { (ekor/periode) }\end{array}$ & \multicolumn{1}{|l|}{ Biaya (Rp) } & Penerimaan (Rp) & Laba (Rp) \\
\hline Peternak/4 bulan & 2 & $550.000,0$ & $980.330,9$ & $430.330,9$ \\
\hline Pedagang/1 bulan & 5 & 3.222 .153 & $3.669 .683,9$ & $447.530,9$ \\
\hline Penjual sate/bulan & 14,67 & $12.343 .585,1$ & $15.501 .300,0$ & $3.157 .714,9$ \\
\hline
\end{tabular}

Tabel 6. Nilai net profit margin (NPM) dan operating ratio tataniaga domba

\begin{tabular}{|l|c|c|}
\hline Lembaga tataniaga & NPM (\%) & OR (\%) \\
\hline Peternak & 43,90 & 56,10 \\
\hline Pedagang & 12,20 & 87,80 \\
\hline Penjual sate & 20,37 & 79,63 \\
\hline
\end{tabular}




\section{Profitabilitas}

Profitabilitas dapat digunakan sebagai indikator untuk mengetahui efisiensi usaha dalam tataniaga ternak domba. Laba bersih masing-masing lembaga tataniaga ternak domba, di kabupaten Sleman selama satu periode tertera pada Tabel 5. Berdasarkan Tabel tersebut, penjual sate mempunyai tingkat laba bersih paling tinggi dibanding lembaga tataniaga yang lain. Nilai net profit margin (NPM) dan operating ratio (OR) dari lembaga tataniaga domba tertara dalam Tabel 6. Dari analisis NPM dan OR dapat diketahui efisiensi tataniaga, semakin tinggi NPM dan semakin rendah OR suatu lembaga tataniaga akan semakin efisien karena semakin rendah biaya tataniaga yang dikeluarkan. Dari tabel tersebut menunjukkan bahwa peternak domba mempunyai efisiensi yang cukup baik dibandingkan lembaga tataniaga lainnya.

\section{KESIMPULAN}

Dari hasil penelitian disimpulkan bahwa saluran tataniaga domba di kabupaten Sleman, sebagian besar menggunakan saluran tata niaga tidak langsung dengan melibatkan sejumlah blantik dan pedagang. Biaya tertinggi dalam pemasaran domba pada pedagang adalah biaya transportasi dan pendapatan terbesar dalam rantai tataniaga domba diperoleh pada pedagang sate. Domba jantan memberikan margin lebih besar daripada domba betina tetapi farmer share domba betina lebih besar daripada domba jantan. Peternak domba mempunyai koefisien kompetitif lebih besar dibanding lembaga tataniaga lainnya.

\section{DAFTAR PUSTAKA}

Abdulgani, I.A. 1981. Beberapa ciri populasi kambing di Desa Ciburuy dan Cigombong serta kegunaan bagi peningkatan. Thesis. Fakultas Peternakan, IPB. Bogor.

Hanafiah, A.M dan A.M. Saefuddin, 1986. Tataniaga hasil perikanan. Cetakan kedua. UI Press. Jakarta.

Limbong, H dan Sitorus, P. 1987. Pengantar tataniaga pertanian. Institut Pertanian Bogor, Jakarta.

Sudaryanto, B. 1989. Dinamika populasi kambing di Lampung. Proceeding Seminar Nasional Hasil Penelitian dan Pengembangan Peternakan. Fakultas Peternakan, Universitas Gadjah Mada, Yogyakarta.

Wiguna, A. 1984. Analisa marketing margin air susu sapi di Daerah Boyolali, Jawa Tengah. 